Jurnal Sporta Saintika

P-ISSN 2502-5651

E-ISSN 2579-5910

\title{
PENGARUH LATIHAN SENAM AEROBIK TERHADAP PENURUNAN BERAT BADAN, PERSENTASE LEMAK TUBUH DAN PENINGKATAN MASSA OTOT
}

\author{
Siska, S.Si., M.Pd ${ }^{1}$, Amrizal, S.Pd, M.Pd ${ }^{2}$ \\ ${ }^{12}$ STKIP Rokania' Program Studi Pendidikan Jasmani Kesehatan dan Rekreasi, Pasir \\ Pengaraian, Indonesia \\ siskazb36@gmail.com,amrizalputrakampar@gmail.com
}

\begin{abstract}
This study aims to reveal 1) The effect of aerobic exercise on weight loss 2) The effect of aerobic exercise on the proportion of fat body, and 3) the effect of aerobic exercise or increasing muscle mass. This research uses quasi-experimental (quasi-experiment). The population is all members of the gymnastics fit club Simpang D Rokan Hulu Regency, with a sample of 10 people. The sampling technique was carried out by total sampling with a total of 10 people. The research instruments for obtaining data were: (1) Tanita BC-541 innerscan digital body scale to measure body weight, (2) skin fold calipers to measure body proportions and (3) Tanita BC-541 innerscan digital body scale for body composition to measure body weight. The data analysis technique used is the t test. The results and data analysis showed that: (1) Aerobic exercise had a significant effect on weight loss tcoun 2. $186>$ ttable 1.782 . The average value of pretest is $66.86 \mathrm{~kg}$ and posttest is $66.12 \mathrm{~kg}$. there was a decrease of $0.74 \mathrm{~kg}$. (2) Aerobic exercise has a significant effect on decreasing the proportion of the body tcount 3. 285> ttable 1. 782. The average pretest score was $40.45 \%$ and posttest $37.18 \%$, there was a decrease of $3.27 \%$. (3) Aerobic exercise has a significant effect on muscle mass tcount 1,835> table 1,782. The pretest means score was 37.72 and posttest 37.63 , there was a decrease of 0.09
\end{abstract}

Keywords: Aerobic Exercise, Body Weight, Body Fat, Muscle Mass.

\begin{abstract}
Abstrak
Penelitian ini bertujuan untuk mengungkap 1) Pengaruh latihan senam aerobik terhadap penurunan berat badan 2) Pengaruh latihan senam aerobik terhadap persentase lemak tubuh, dan 3) Pengaruh latihan senam aerobik terhadap peningkatan massa otot. Penelitian mengunakan eksperimen semu (quasi-exsperiment). Populasi adalah semua anggota senam fit club simpang D Kabupaten Rokan Hulu, dengan sampel berjumlah 10 orang. Teknik pengambilan sampel dilakukan dengan total sampling dengan jumlah 10 orang. Instrumen penelitian untuk memperoleh data adalah: (1) Timbangan badan digital innerscan Tanita BC-541 body composition untuk mengukur berat badan, (2) Skin fold caliper untuk mengukur persentase lemak tubuh dan (3) Timbangan badan digital innerscan Tanita BC541 body composition untuk mengukur massa otot. Teknik analisa data yang digunakan adalah uji t. Hasil dan analisa data menunjukkan bahwa: (1) Latihan senam aerobik memberikan pengaruh yang signifikan terhadap penurunan berat badan $t_{\text {hitung }} 2,186>t_{\text {tabel }}$ 1. 782 . Nilai rata-rata pretest $66,86 \mathrm{~kg}$ dan posttest $66,12 \mathrm{~kg}$. Terdapat penurunan $0,74 \mathrm{~kg}$. (2) Latihan senam aerobik memberikan pengaruh yang signifikan terhadap penurunan persentase lemak tubuh thitung 3, $285>t_{\text {tabel }} 1$. 782. Nilai rata-rata pretest $40.45 \%$ dan posttest 37, $18 \%$, Terdapat penurunan 3, $27 \%$.(3) Latihan senam aerobik memberikan pengaruh yang signifikan terhadap massa otot $t_{\text {hitung }} 1,835>t_{\text {tabel }} 1$. 782. Nilai rata-rata pretest 37, 72 dan posttest 37, 63, Terdapat penurunan 0, $09 \%$.
\end{abstract}

Kata kunci: Senam Aerobik, Berat Badan, Lemak Tubuh, Massa Otot

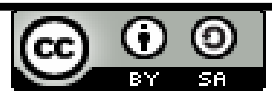


Jurnal Sporta Saintika

P-ISSN 2502-5651

E-ISSN 2579-5910

\section{PENDAHULUAN}

Kebugaran jasmani/kesegaran jasmani merupakan suatu elemen fisik yang mempengaruhi penampilan performance, (Siska, 2019). Kondisi ini sangat bergantung pada komponen kesegaran jasmani dan motorik. Menurut (Jasmani, 2017) mengemukakanKebugaran jasmani atau physical fitness dapat diartikan sebagai kondisi jasmani yang menggambarkan kebugaran jasmani atau dapat pula diartikan sebagai kemampuan seseorang untuk melakukan suatu pekerjaan tertentu dengan baik tanpa mengalami kelelahan yang berarti.

Meningkatkan kebugaran jasmani dapat dilakukan dengan olahraga senam aerobik. Senam aerobik dalam (Indah, 2016) mengemukakan, bahwa senam aerobik adalah latihan yang dilakukan untuk membakar lemak sambil memperbaiki kekencangan otot yang dipimpin oleh pelatih berpengalaman secara bersama-sama dengan diiringi musik yang sesuai dengan irama/gerakan untuk anggota tubuh yang bergerak. Anggota senam power fit mengikuti latihan senam aerobik untuk penurunan berat badan, lemak tubuh dan peningkatan massa otot.

Permasalahan penelitian ini adalah berdasarkan observasi di lapangan pada umumnya setelah melakukan olahraga senam aerobik, anggota senam mengalami peningkatan kelebihan berat badan, peningkatan lemak tubuh dan peningkatan massa otot. Hal tersebut disebabkan pengaturan diet/pola makan yang tidak terkontrol, biasanya selesai melakukan aktivitas olahraga nafsu makan akan meningkat. Anggota senam tidak bisa mengontrol pola makan/pemenuhan asupan gizi yang tidak seimbang dapat menyebabkan obesitas.

Ditemukan dilapangan seperti anggota senam dalam melakukan latihan tidak kontiniu, karena secara prinsip latihan kalau sudah 2 kali 24 jam tidak melakukan aktifitas olahraga keadaan kondisi tubuh akan kembali kekondisi semula. Instruktur kurang memahami apa yang harus dikuasai sebagai instruktur seperti, cek denyut nadi. Cek denyut nadi sangat diperlukan, karena bisa melihat kebugaran seseorang dan menentukan program latihan. Kurang motivasi dan tidak disiplin dalam melakukan gerakan senam, itu terlihat saat melakukan aktifitas senam. Anggota senam kalau sudah merasa lelah ia akan langsung istirahat dan ada tidak melanjudkan latihan tersebut. Untuk mendapatkan hasil yang baik dan keluwesan dalam gerakan yang dilakukan harus diperhatikan perlengkapan sarana dan prasarana, untuk sarana dan prasarana belum ada perlengkapan olahraga senam yang menggunakan pembebanan, seperti matras, barbel, diklik, sebagai kelengkapan sebagai tempat pelaksanaan senam aerobik kaca sangatlah dibutuhkan, karena dapat meningkatkan sportasaintika.ppj.unp.ac.id 
Jurnal Sporta Saintika

P-ISSN 2502-5651

E-ISSN 2579-5910

rasa percaya diri.

Latihan senam aerobik merupakan rangkaian aktivitas gerak yang dominan merangsang kemampuan metabolisme yaitu kardiovaskuler. Menurut (Gusvominesia et al., 2019) manfaat dan keuntungan senam aerobik yaitu: 1) kerja jantung lebih efisien dan menjadi terlatih, sehingga jantung tidak cepat lelah, 2) pembuluh darah akan semakin lebih besar,sehingga darah akan lebih lancar dibandingkan dengan orang yang tidak terlatih, 3) mencegah terjadinya pengumpalan darah, 4) jantung akan dapat memompakan darah lebih banyak dan berdenyut lebih lambat, 5) paru- paru akan bertambah kapasitas pernafasannya, 6) berkurangnya resiko gangguan pada jantung, 7) Tekanan darah yang sebelumnya tinggi akan menurun secara teratur, dan 8) terjadi penurunan kadar lemak yang membahayakan di dalam darah, dan terjadinya kadar lemak yang baik sehingga bermanfaat dalam tubuh. Latihan senam aerobik yang dilakukan secara teratur dan terprogram bermanfaat terhadap kerja fungsi organ tubuh lebih efisien, terutama jantung dan paru-paru. Peredaran darah lancar keseluruh tubuh, otot menjadi kuat, akan terjadi peningkatan massa otot, penurunan persentase kadar lemak tubuh.

Berat badan merupakan gambaran massa indek tubuh. ( dkk Supariasa, I Dewa Nyoman, 2002), mengemukakan bahwa, Berat badan adalah salah satu parameter yang memberikan gambaran massa tubuh. Massa tubuh yang berlebih di dalam tubuh akan menggambarkan kelebihan berat badan yang dikenal dengan istilah obesitas, dimana menunjukkan adanya penumpukkan lemak tubuh yang melebihi batas normal di dalam tubuh. (Ramayulis, 2008) mengemukakan, "Faktor penyebab terjadinya obesitas adalah faktor genetik, kerusakan pada salah satu bagian otak, pola makan berlebih, kurang bergerak atau kurang berolahraga, ketidakstabilan emosi, dan lingkungan". Lemak merupakan salah satu komponen dalam tubuh yang berfungsi sebagai pembentukan energy bagi tubuh beraktivitas setiap harinya. (Lingga, 2012) menyatakan fungsi lemak adalah bukan saja menjadi penyusun bangunan tubuh, namun juga memiliki fungsi yang cukup beragam bagi berlangsungnya kehidupan.

Keberadaan lemak dalam tubuh tergambar pada persentase lemak. Persentase lemak tubuh merupakan gambaran seberapa besar atau banyaknya lemak yang ada dalam tubuh. Persentase lemak tubuh bisa bertambah dan bisa menurun efek dari aktivitas dan pola konsumsi makan setiap harinya. Persentase lemak tubuh dapat diukur secara tidak langsung melalui pengukuran tebal lipatan kulit diberbagai bagian tubuh dengan memakai alat Skin Fold Caliper" (Depdikbud, 1996). Untuk lebih jelasnya kategori persentase lemak tubuh dapat dilihat pada tabel 1. 
Jurnal Sporta Saintika

P-ISSN 2502-5651

E-ISSN 2579-5910

Tabel 1. Norma Persentase Lemak Tubuh Wanita

\begin{tabular}{|c|c|}
\hline Usia & Proposentase Lemak Tubuh \\
\hline s.d -30 tahun & $14-21 \%$ \\
\hline $30-50$ tahun & $15-23 \%$ \\
\hline $50-70$ tahun & $16-26 \%$ \\
\hline
\end{tabular}

Sumber: (Depdikbud, 1996)

Antara berat badan dengan masa otot ada keterkaitannya, peningkatan berat badan adalah menambah massa otot. Artinya menambah berat badan sama dengan membah massa otot. Massa otot merupakan besar kecilnya bentuk/berat otot. (Sherwood, 2011) mengemukakan bahwa, otot adalah spesialis kontraksi tubuh. Massa otot (berat otot) adalah sekumpulan dari apapun yang ada pada otot. (Wiarto, 2013) mengemukakan otot merupakan alat gerak aktif. Otot adalah sebuah jaringan konektif yang tugas utamanya untuk menggerakkan bagian-bagian tubuh baik disadari maupun yang tidak. Kalau fungsi otot tidak berperan kita tidak bisa bergerak, kaku dan otot tidak bisa berkontraksi sebagai mana fungsi sesungguhnya.

Fungsi otot yang berbeda-beda sarkolema adalah berfungsi sebagai pelindung otot, sarkoplasma untuk tempat dimana miofibril dan miofilamen berada, miofibril merupakan serat-serat pada otot, miofilamen adalah benang-benang/filamen halus yang berasal dari myofibril. latihan fisik secara rutin dapat membakar lemak, meningkatkan masa otot dan kecepatan metabolisme tubuh, sehingga seiring perubahan fisiologis dapat mempertahankan berat badan yang sesuai (Nurhidayah, n.d.)

Berdasarkan dari kutipan di atas, keberadaan persentase lemak tubuh dan massa otot akan menggambarkan berat badan. Lemak tubuh yang berlebih akan berdampak kepada kelebihan berat badan. Untuk mengatasi keseimbangan lemak tubuh dan massa tubuh terhadap berat badan dapat dinetralisasikan dengan melakukan latihan olahraga salah satunya melalui latihan senam aerobik. Terdapat pengaruh aktivitas fisik (senam aerobik) pada kelompok intervensi terhadap penurunan berat badan (Pratiwi \& Basri, 2018). Latihan senam aerobik dengan intensitas rendah sampai sedang yaitu 50\%-80\% dari denyut nadi maksimal merupakan takaran dalam memberikan beban latihan. Latihan yang berlangsung selama 15 menit sampai 1 jam adalah batasan tubuh melakukan latihan dalam memberikan efek terhadap perbaikan sistem organisme peningkatan fungsi fisiologis tubuh agar bekerja secara optimal (Indah, 2016) Berarti, melakukan latihan senam aerobik dapat menurunkan berat badan. Selama latihan senam aerobik berlangsung, lemak yang berlebih di dalam 
Jurnal Sporta Saintika

P-ISSN 2502-5651

E-ISSN 2579-5910

tubuh akan dimanfaatkan sebagai sumber energi. Makin sering orang yang memiliki kelebihan kadar lemak di dalam tubuhnya untuk melakukan latihan senam aerobik, maka memungkinkan pembakaran lemak di dalam tubuh akan lebih maksimal. Hasil penelitian menunjuk- kan bahwa latihan senam aerobik terbukti menurunkan berat badan sebesar 66, $78 \%$, persen lemak tubuh sebesar $86,42 \%$ (Utomo, 2012). Dengan begitu, latihan senam aerobik dapat menurunkan kadar lemak tubuh.

Hasil penelitian (Siska, 2014) menunjukkan, (1) latihan senam aerobik multi impact memberikan pengaruh yang signifikan terhadap terhadap massa otot sebesar 0,34 , (2) Latihan senam aerobik low impact memberikan pengaruh yang signifikan terhadap massa otot sebesar 0,18 . Berarti, latihan senam aerobik baik multi maupun low impact memberikan pengaruh terhadap massa otot

Berdasarkan beberapa pendapat yang diuraikan peneliti merasa perlu untuk melakukan penelitian untuk mengungkapkan sejauhmana pengaruh latihan senam aerobik terhadap penurunan berat badan, persentase lemak tubuh dan peningkatan massa otot. Hasil penelitian ini nantinya diharapkan dapat menambah wawasan para pembaca dan pihak terkait demi memajukan pengetahuan mengenai senam aerobik dan lemak tubuh.

\section{METODELOGI PENELITIAN}

Metode penelitian yaitu eksperimen semu (quasi-exsperiment). menurut (Sihombing, 2011) menyatakan tujuan rancangan eksperimen semu adalah "untuk memperoleh informasi yang merupakan perkiraan bagi informasi yang dapat diperoleh dengan eksperimen yang sebenarnya dalam keadaan yang tidak memungkinkan untuk mengontrol dan/atau memanipulasikan semua variabel yang relevan". Memberikan perlakuan latihan senam aerobik sesuai program latihan.

Adapun skema rancangan penelitian tergambar sebagai berikut:

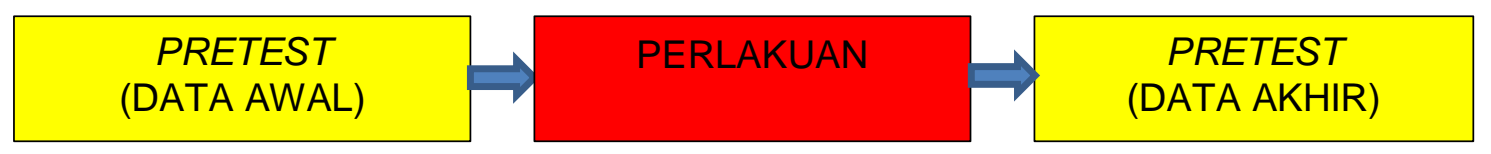

\section{Gambar 1. Skema: Rancangan Penelitian}

Populasi penelitian ini adalah seluruh anggota senam Fit Clup Simpang D Desa Kabupaten Rokan Hulu Riau sebanyak 10 orang, dengan sampel berjmlah 10 orang dengan total sampling. Penelitian ini dilaksanakan di Simpang D Kabupaten Rokan Hulu Riau

Instrumen penelitian yang digunakan untuk memperoleh data penelitian ini di antaranya: (1) Timbangan badan digital innerscan Tanita BC-541 body composition untuk mengukur berat badan, (2) Skin fold caliper untuk mengukur persentase lemak tubuh dan (3) 
Jurnal Sporta Saintika

P-ISSN 2502-5651

E-ISSN 2579-5910

Timbangan badan digital innerscan Tanita BC-541 body composition untuk mengukur massa otot. Teknik analisa data yang digunakan adalah uji t dikemukan oleh (Arikunto, 2006) dengan rumus sebagai berikut:

$$
\mathrm{t}=\frac{M d}{\sqrt{\frac{\sum x^{2} d}{N(n-1)}}}
$$

Keterangan:

$\mathrm{Md}=$ Mean dari perbedaan per test dengan post test

$\Sigma x^{2} \mathrm{~d}=$ Jumlah kuadrat deviasi

$\mathrm{N} \quad=$ Jumlah sampel

Indikator capaian penelitian ini adalah (1) terdapat penurunan berat badan dengan melakukan latihan senam aerobik, (2) terdapat penurunan persentase lemak tubuh dengan melakukan latihan senam aerobik dan (3) terdapat peningkatan massa otot dengan melakukan latihan senam aerobik.

\section{HASIL PENELITIAN}

\section{Pengaruh Latihan Senam Aerobik Terhadap Penurunan Berat Badan}

Data pretest dan postes Pengaruh latihan senam aerobik terhadap penurunan berat badan Pada anggota senam Fit Clup Simpang D Kabupaten Rokan Hulu pada tabel berikut ini:

\section{Tabel 2. Distribusi Frekuensi Data Pretest dan Postest Pengaruh latihan Senam Aerobik terhadap Penurunan Berat Badan}

\begin{tabular}{|c|c|c|c|c|}
\hline \multirow{2}{*}{ Kelas interval } & \multicolumn{3}{|c|}{ Pre test } & \multicolumn{2}{c|}{ Post test } \\
\cline { 2 - 5 } & \multicolumn{3}{|c|}{ Frekuensi } \\
\cline { 2 - 5 } & Absolut & Relatif & Absolut & Relatif \\
\hline$>80.33$ & 1 & 10 & 1 & 10 \\
\hline $71.10-80.33$ & 1 & 10 & 1 & 10 \\
\hline $61.88-71.10$ & 4 & 40 & 4 & 40 \\
\hline $52.65-61.88$ & 4 & 40 & 4 & 40 \\
\hline$<52.65$ & 0 & 0 & 0 & 0 \\
\hline Jumlah & 10 & 100 & 10 & 100 \\
\hline
\end{tabular}

Berdasarkan tabel di atas, diperoleh data pre test dengan berat tertinggi sebesar 86 , $30 \mathrm{Kg}$, berat terendah sebesar $56,30 \mathrm{Kg}$ dengan berat rata-rata sebesar $66,86 \mathrm{Kg}$. Sedangkan data post test dengan berat tertinggi sebesar $84,90 \mathrm{Kg}$, berat terendah sebesar $55,30 \mathrm{Kg}$ dengan berat rata-rata sebesar 66,12 Kg. Disimpulkan, Pengaruh latihan senam 
Jurnal Sporta Saintika

P-ISSN 2502-5651

E-ISSN 2579-5910

aerobik terhadap penurunan berat badan Pada anggota senam Fit Clup Simpang D Kabupaten Rokan Hulu adalah sedang dan kurang. Untuk jelasnya paparan tabel di atas terlihat jelas pada gambar di bawah ini:

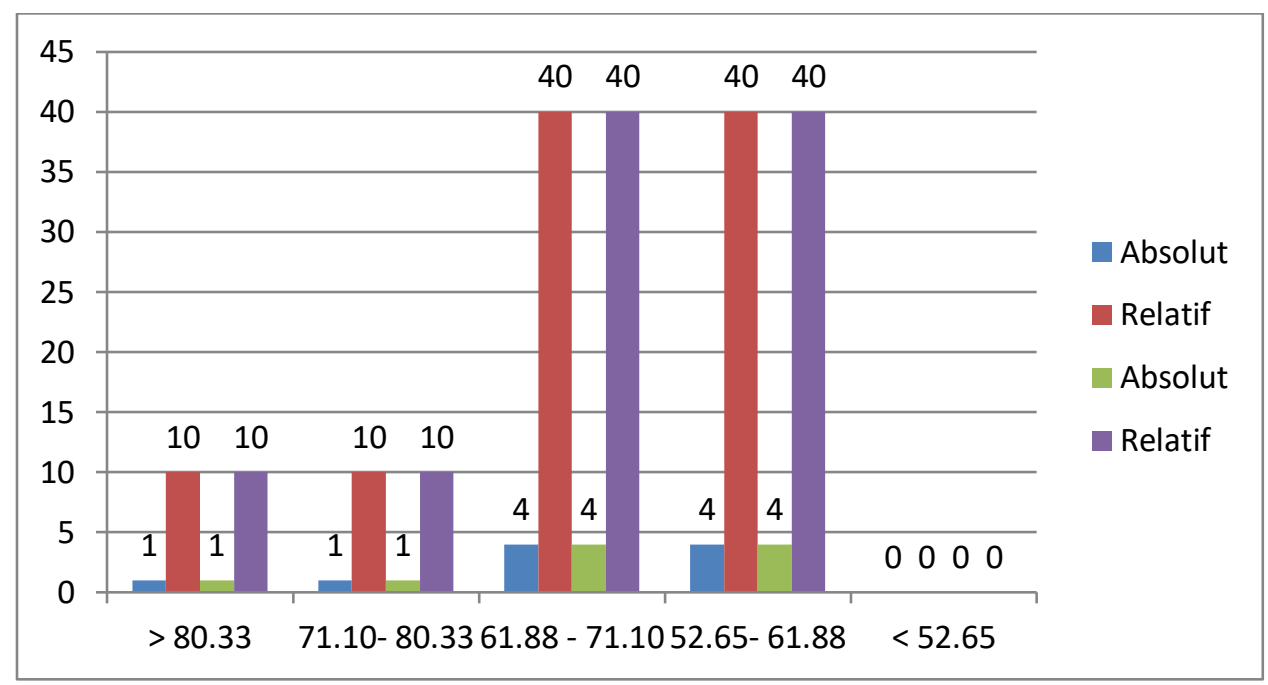

Gambar 2. Grafik Histogram Distribusi Frekuensi Data Pretest dan Postes Pengaruh Latihan Senam Aerobik Terhadap Penurunan Berat Badan

\section{Pengaruh Latihan Senam Aerobik terhadap Penurunan Persentase Lemak Tubuh}

Data pretest dan postes pengaruh latihan senam aerobik terhadap penurunan persentase lemak tubuh pada anggota senam Fit Clup Simpang D, Kabupaten Rokan Hulu pada tabel berikut ini:

Tabel 2.

Distribusi Frekuensi Data Pretest dan Postes Pengaruh Latihan Senam Aerobik terhadap Penurunan Persentase Lemak Tubuh

\begin{tabular}{|c|c|c|c|c|}
\hline \multirow{2}{*}{ Kelas interval } & \multicolumn{2}{|c|}{ Pre test } & \multicolumn{2}{c|}{ Post test } \\
\cline { 2 - 5 } & \multicolumn{4}{|c|}{ Frekuensi } \\
\cline { 2 - 5 } & Absolut & Relatif & Absolut & Relatif \\
\hline$>44.69$ & 1 & 10.00 & 0 & 0.00 \\
\hline $40.77-44.69$ & 3 & 30.00 & 3 & 30.00 \\
\hline $36.86-40.77$ & 4 & 40.00 & 2 & 20.00 \\
\hline $32.94-36.86$ & 2 & 20.00 & 4 & 40.00 \\
\hline$<32.94$ & 0 & 0.00 & 1 & 10.00 \\
\hline Jumlah & 10 & 100 & 10 & 100 \\
\hline
\end{tabular}


Jurnal Sporta Saintika

P-ISSN 2502-5651

E-ISSN 2579-5910

Berdasarkan tabel di atas, diperoleh data pre test dengan persentase lemak tubuh tertinggi sebesar 45. 50, persentase lemak tubuh terendah sebesar 35.60 dengan persentase lemak tubuh rata-rata sebesar 40. 45. Sedangkan data post test dengan persentase lemak tubuh tertinggi sebesar 42. 90, persentase lemak tubuh terendah sebesar 31.90 dengan persentase lemak tubuh rata-rata sebesar 37. 18. Disimpulkan, Pengaruh latihan senam aerobik terhadap persentase lemak tubuh pada anggota senam Fit Clup di Simpang D, Desa Ramba Jaya, Kabupaten Rokan Hulu adalah sedang dan kurang. Untuk jelasnya paparan tabel di atas terlihat jelas pada gambar di bawah ini:

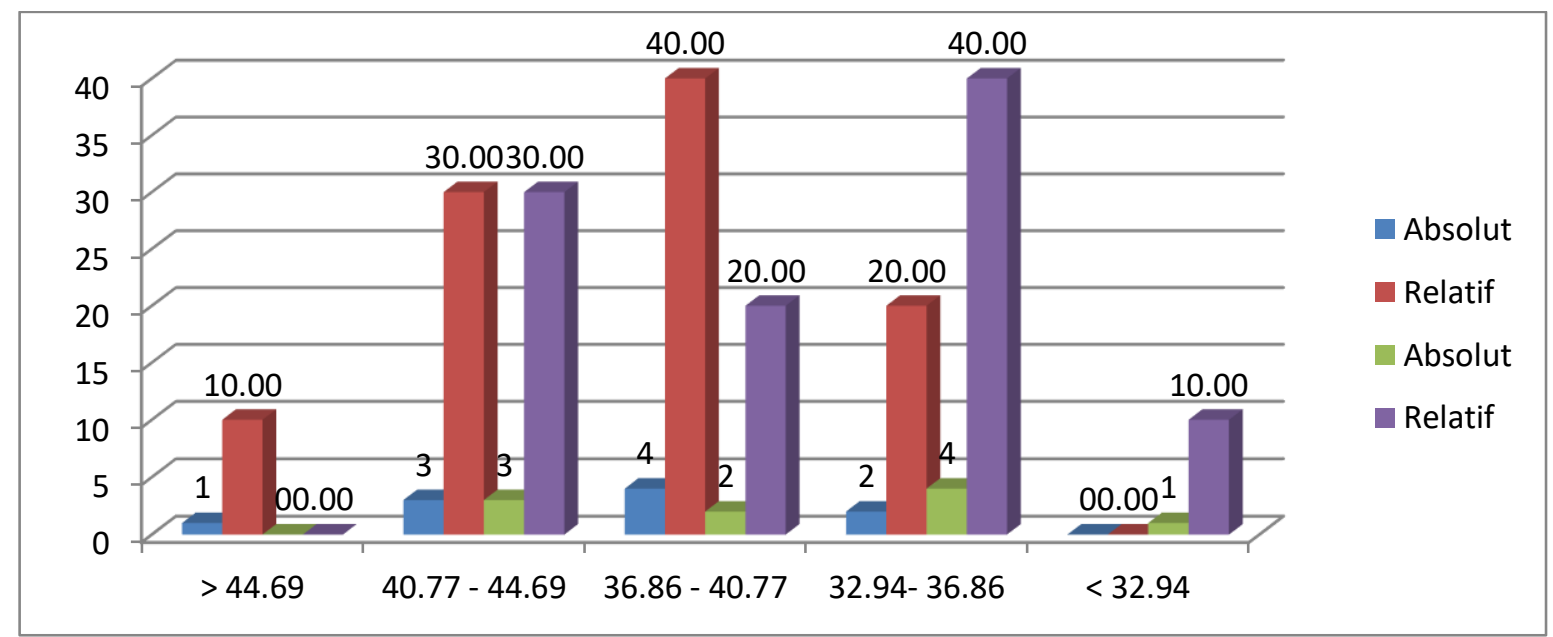

Gambar 2. Grafik Histogram Distribusi Frekuensi Data Pretest dan Postes Pengaruh Latihan Senam Aerobik Terhadap Penurunan Persentase Lemak Tubuh

\section{Pengaruh Latihan Senam Aerobik Terhadap Peningkatan Massa Otot}

Data pretest dan postes pengaruh latihan senam aerobik terhadap peningkatan massa otot Pada anggota senam Fit Clup di Simpang D Kabupaten Rokan Hulu pada tabel berikut ini:

Tabel 3. Distribusi Frekuensi Data Pretest dan Postes Pengaruh Latihan Senam Aerobik terhadap Peningkatan Massa Otot

\begin{tabular}{|c|c|c|c|c|}
\hline \multirow{2}{*}{ Kelas interval } & \multicolumn{2}{|c|}{ Pre test } & \multicolumn{2}{c|}{ Post test } \\
\cline { 2 - 5 } & \multicolumn{4}{|c|}{ Frekuensi } \\
\cline { 2 - 5 } & Absolut & Relatif & Absolut & Relatif \\
\hline$>41.36$ & 1 & 10.00 & 1 & 10.00 \\
\hline $38.90-41.36$ & 1 & 10.00 & 1 & 10.00 \\
\hline $36.45-38.90$ & 4 & 40.00 & 4 & 40.00 \\
\hline $33.99-36.45$ & 4 & 40.00 & 4 & 40.00 \\
\hline
\end{tabular}


Jurnal Sporta Saintika

P-ISSN 2502-5651

E-ISSN 2579-5910

\begin{tabular}{|c|c|c|c|c|}
\hline$<33.99$ & 0 & 0.00 & 0 & 0.00 \\
\hline Jumlah & 10 & 100 & 10 & 100 \\
\hline
\end{tabular}

Massa otot tertinggi sebesar 42. 90, massa otot terendah sebesar 34 . 60 dengan massa otot rata-rata sebesar 37. 72. Sedangkan data post test dengan massa otot tertinggi sebesar 42. 60, massa otot terendah sebesar 34. 60 dengan persentase lemak tubuh ratarata sebesar 37. 63. Disimpulkan, Pengaruh latihan senam aerobik terhadap massa otot pada anggota senam Fit Clup Simpang D Kabupaten Rokan Hulu adalah kurang. Untuk jelasnya paparan tabel di atas terlihat jelas pada gambar di bawah ini:

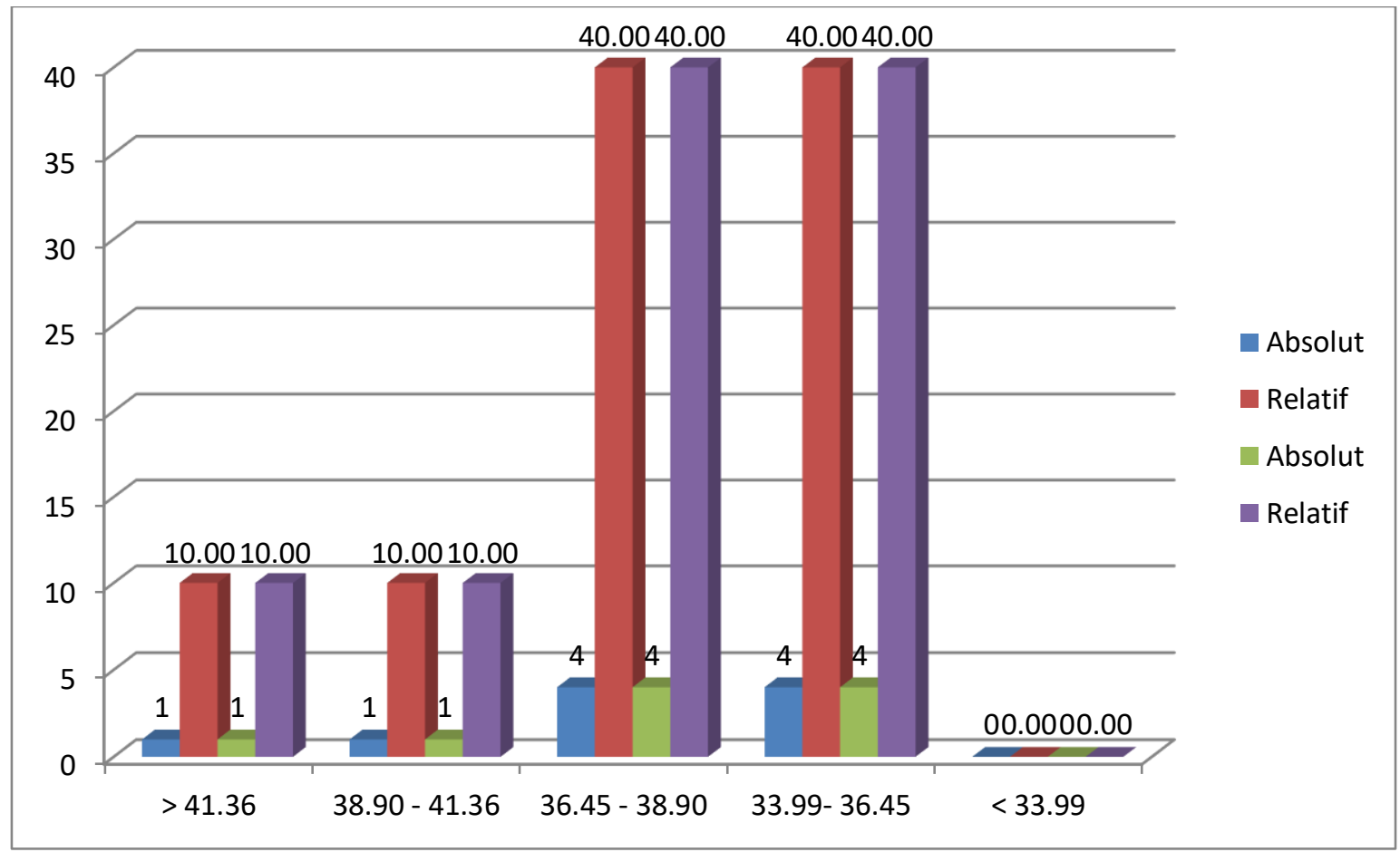

\section{Grafik Histogram Distribusi Frekuensi Data Pretest dan Postes Pengaruh Latihan Senam Aerobik terhadap Peningkatan Massa Otot}

Berdasarkan hasil penelitian data pretest dan posttest, maka diperoleh hasil analisa data yang terpapar pada tabel di bawah ini:

Tabel 3. Analisa Data Penelitian

\begin{tabular}{|l|l|l|l|l|l|l|l|}
\hline \multirow{2}{*}{ Keterangan } & \multicolumn{3}{|l|}{ Mean } & $\begin{array}{l}\text { Taraf } \\
\text { signifikan }\end{array}$ & $t_{\text {tabel }}$ & thitung & Keterangan \\
\cline { 2 - 9 } & Pretest & Posttest & Selisih & & \\
\hline Berat Badan & 66,86 & 66,12 & 0,74 & $5 \%$ & 1.812 & 2,186 & Signifikan \\
\hline Lemak Tubuh & 40,45 & 37,18 & 3,27 & $5 \%$ & 1.812 & 3,285 & Signifikan \\
\hline Mass Otot & 37,72 & 37,63 & 0,09 & $5 \%$ & 1.812 & 1,835 & Signifikan \\
\hline
\end{tabular}


Jurnal Sporta Saintika

P-ISSN 2502-5651

E-ISSN 2579-5910

Berdasarkan tabel analisa data tentang berat badan di atas tertera t hitung diperoleh sebesar 2,186 sedangkan $t$ tabel sebesar 1, 782, maka $t t_{\text {hitung }}>t t_{t a b e l}$ yaitu 2, $186>1.782$. Dengan demikian dapat diartikan bahwa latihan senam aerobik berpengaruh yang signifikan terhadap penurunan berat badan anggota senam Fit Club Simpang D Kabupaten Rokan Hulu. Hal ini tergambar dari selisih latihan senam aerobik pada berat badan yaitu pre test $(66,86)$ dan post test $(66,12)$ dengan perhitungan selisih menjadi $(0,74)$ artinya disini bahwa latihan senam aerobik berpengaruh terhadap penurunan berat badan anggota senam Fit Club Simpang D Kabupaten Rokan Hulu.

Untuk lemak tubuh di atas tertera t hitung diperoleh sebesar 3, 285 sedangkan t tabel sebesar 1, 782, maka $t t_{\text {hitung }}>t t_{\text {tabel }}$ yaitu 3, $285>1$. 782. Dengan demikian dapat diartikan bahwa latihan senam aerobik berpengaruh yang signifikan terhadap penurunan persentase lemak tubuh anggota senam Fit Club Simpang D Kabupaten Rokan Hulu.Hal ini tergambar dari selisih latihan senam aerobik pada lemak tubuh yaitu pre test $(40,45)$ dan post test $(37$, 18) dengan perhitungan selisih menjadi $(3,27)$ artinya disini bahwa latihan senam aerobik berpengaruh terhadap penurunan persentase lemak tubuh annggota senam Fit Club Simpang D Kabupaten Rokan Hulu.

Sedangkan pada massa otot di atas tertera $t$ hitung diperoleh sebesar 1, 835 sedangkan $t$ tabel sebesar 1,782 , maka $t t_{\text {hitung }}>t t_{\text {tabel }}$ yaitu $1,835>1$. 782 . Dengan demikian dapat diartikan bahwa latihan senam aerobik berpengaruh yang signifikan terhadap penurunan massa otot anggota senam Fit Club Simpang D Kabupaten Rokan Hulu.Hal ini tergambar dari selisih latihan senam aerobik pada masa otot yaitu pre test $(37,72)$ dan post test $(37,63)$ dengan perhitungan selisih menjadi $(0,09)$ artinya disini bahwa latihan senam aerobik berpengaruh terhadap penurunan massa otot annggota senam Fit Club Simpang D Kabupaten Rokan Hulu.

\section{PEMBAHASAN}

Untuk menurunkan berat bada, persentase lemak tubuh dan peningkatan massa otot pada anggota senam Fit Clup di Simpang D Kabupaten Rokan Hulu maka diberikan latihan senam aerobik. Dari penggunaan latihan ini akan dilihat apakah ada pengaruh latihan senam aerobik terhadap penurunan berat badan, penurunan persentase lemak tubuh dan peningkatan massa otot pada anggota ozone fitness dan aerobik.

Dalam pelaksanaan penelitian untuk mendapatkan data, pertama kali dilakukan tes awal. Tes awal ini bertujuan untuk melihat penuruanan berat badan, penurunan persentase lemak tubuh dan peningkatan massa otot pada anggota senam Fit Clup di Simpang D Kabupaten Rokan Hulu pada senam aerobik. 
Jurnal Sporta Saintika

P-ISSN 2502-5651

E-ISSN 2579-5910

Untuk itu perlu kiranya pengkajian tentang metodologi dan kajian teori dari suatu penelitian. Pengetahuan yang diperoleh melalui pendekatan ilmiah dan dibuat berdasarkan teori tertentu secara sistematis dan dilakukan sesuai dengan langkah-langkah atau prosedur yang benar dengan demikian hasil penelitian ini dapat diterima kebenarannya.

\section{Latihan Senam Aerobik Berpengaruh terhadap Penurunan Berat Badan}

Pada hasil post test latihan senam aerobik terdapat berat badan, yaitu dari skor rata-rata $66,86 \mathrm{~kg}$ pada pre test menjadi $66,12 \mathrm{~kg}$ pada post test dengan selisih 0, 74 . Terjadinya penurunan berat badan yang disebabkan oleh latihan senam aerobik

Hasil penelitian menunjukkan bahwa $t_{\text {hitung }}(2.186)>t_{\text {tabel }}(2$. 186). Hal ini berarti bahwa hipotesis penelitian dapat diterima. Dengan demikian dapat diartikan bahwa latihan senam aerobik berpengaruh yang signifikan terhadap berat badan anggota senam Fit Clup Simpang D Kabupaten Rokan Hulu.

Untuk penurunan berat badan dengan latihan senam aerobik adalah gerakan yang dilakukan mempunyai benturan ringan dan tidak memiliki lompatan dalam melakukan gerakan. Sehingga latihan senam memberikan pengaruh terhadap penurunan berat badan, keuntungan lainnya latihan senam aerobik adalah dapat digunakan untuk semua umur, baik usia sekolah maupun hingga usia tua.

(D. Supariasa, I Dewa Nyoman, 2002) mengemukakan, bahwa "Berat badan adalah salah satu parameter yang memberikan gambaran massa tubuh. Menurut Irianto (2007: 155) "Kelebihan berat badan di atas $25 \%$ dari berat badan ideal di sebut obesitas. (Septiyadi, 2004) "Seseorang mempunyai berat badan 20\% dari berat badan ideal umumnya dikategorikan obesitas (standar umum : tinggi dikurangi 110)". Berat badan bisa bertambah dan bisa menurun dengan latihan senam aerobik.

Latihan merupakan aktivitas olahraga secara sistematis dalam waktu yang lama, ditingkatkan secara progresif dan individual yang mengarah kepada ciri-ciri fungsi dan psikologis manusia untuk mencapai sasaran yang telah ditentukan. Senam aerobik sebagaiman dijelaskan di atas bahwa suatu rangkaian gerak yang dipilih secara sengaja dengan cara mengikuti irama musik yang sehingga melahirkan kekuatan ritmis, kontinuitas dan durasi tertentu. Dari uraian di atas dapat dikemukakan bahwa dengan senam membantu menurunkan berat badan bagi anggota yang mengikuti latihan secara serius dan teratur. 
Jurnal Sporta Saintika

P-ISSN 2502-5651

E-ISSN 2579-5910

2. Latihan Senam Aerobik Berpengaruh terhadap Penurunan Persentase Lemak Tubuh

Pada hasil post test latihan senam aerobik terdapat persentase lemak tubuh, yaitu dari skor rata-rata 40,45\% pada pre test menjadi 37,18\% pada post test dengan selisih $23,27 \%$. Terjadinya penurunan persentase lemak tubuh ini disebabkan oleh latihan senam aerobik.

Hasil penelitian menunjukkan bahwa $t_{\text {hitung }}(3,285)>t_{\text {tabel }}(1.812)$. Hal ini berarti bahwa hipotesis penelitian dapat diterima. Dengan demikian dapat diartikan bahwa latihan senam aerobik berpengaruh yang signifikan terhadap persentase lemak tubuh anggota senam Fit Clup Simpang D Kabupaten Rokan Hulu. Terjadinya penurunan persentase lemak tubuh menurut (Eka Novita Indra, 2016) aktivitas aerobik yang mempunyai pengaruh besar pada lemak tubuh adalah semua bentuk aktivitas aerobik yang dilakukan pada intensitas rendah sampai sedang. Aktivitas aerobik akan menyebabkan terjadinya penurunan berat badan karena turunnya persentase lemak tubuh.

Penurunan persentase lemak tubuh terlihat setelah melakukan latihan 16 pertemuan. Oleh karena itu, durasi dan program latihan yang teratur dan kontinyu dalam berlatih merupakan syarat yang penting untuk keberhasilan program latihan. Frekuensi latihan senam aerobik yang dilakukan $\geq 3$ kali dalam seminggu memberikan pengaruh yang signifikan terhadap penurunan persentase lemak tubuh. Hal itu dikarenakan metabolisme lemak bekerja dengan baik. Apabila frekuensi latihan dilakukan tiga kali dalam seminggu, waktu istirahat satu hari dan keesokan harinya sudah melakukan latihan, berarti lemak yang tersimpan dalam tubuh tidak terlalu menumpuk dan tidak akan menjadi timbunan lemak di dalam tubuh, karena lemak tersebut akan segera diproses melalui pembakaran lemak pada saat latihan. Latihan menyebabkan proses adaptasi pada organ tubuh.

Bila frekuensi latihan dilakukan 3-5 kali dalam seminggu, itu artinya organ tubuh akan lebih sering menerima rangsangan ataupun beban dari latihan sehingga proses adaptasi akan berpengaruh lebih cepat. Hal tersebut dikarenakan, disaat latihan maka akan terjadi proses adaptasi pada tubuh. Apabila frekuensi latihan ditingkatkan, maka organ tubuh akan beradaptasi terhadap perubahan tersebut dengan baik. Tetapi tubuh membutuhkan waktu untuk istirahat agar tubuh dapat mengadaptasi seluruh beban selama proses latihan. Sebaliknya, frekuensi latihan senam aerobik yang dilakukan $\leq 2$ 
Jurnal Sporta Saintika

P-ISSN 2502-5651

E-ISSN 2579-5910

kali dalam seminggu tidak memberikan pengaruh yang signifikan terhadap penurunan persentase lemak tubuh.

Hal tersebut dikarenakan, dengan jarak latihan yang lama dan penambahan jumlah lemak yang didapatkan dari asupan makanan selama berhari-hari akan menyebabkan lemak tertimbun dengan banyak dan lama, tanpa ada pengurangan lemak dengan proses pembakaran. Ketika latihan kembali, maka tubuh akan memetabolisme lemak dengan kapasitas tertentu dan tidak bisa membakar semua lemak yang sudah tertimbun. Pembakaran lemak yang terjadi tidak memberikan pengaruh yang signifikan terhadap penurunan persentase lemak tubuh bila frekuensi latihan senam aerobik yang hanya dilakukan 1-2 kali seminggu. Dengan kata lain, jika hanya melakukan latihan dua hari perminggu, maka hasilnya hanya sedikit lebih baik daripada tidak melakukan latihan. Dengan demikian frekuensi latihan juga menentukan dalam memberikan pengaruh terhadap penurunan persentase lemak tuh. Dapat disimpulkan latihan senam aerobik yang dilakukan secara terprogram, terstruktur dengan pengaturan intensitas, frekuensi, dan durasi akan memberikan pengaruh besar terhadap penurunan persentase lemak tubuh.

\section{Latihan Senam Aerobik Berpengaruh terhadap Massa Otot.}

Pada hasil post test latihan senam aerobik terdapat massa otot, yaitu dari skor rata-rata 37, 72 pada pre test menjadi 37, 63 pada post test dengan selisih 0, 09. Berdasarkan data yang ditemukan terjadinya penurunan massa otot ini disebabkan oleh latihan senam aerobik.

Hasil penelitian menunjukkan bahwa thitung $(1,835)>t_{\text {tabel }}(1.812)$. Hal ini berarti bahwa hipotesis penelitian dapat diterima. Dengan demikian dapat diartikan bahwa latihan senam aerobik berpengaruh yang signifikan terhadap massa otot anggota senam Fit Clup Simpang D Kabupaten Rokan Hulu. Untuk massa otot banyak sekali faktorfaktor lain di antaranya, dengan berolahraga senam aerobik akan terjadi perubahanperubahan dalam otot adalah perubahan anatomis yaitu membesarnya serabut-serabut otot (hipertrofi otot), bertambahnya jumlah kapiler didalam otot (kapilarisasi otot), bertambahanya jumlah jaringan ikat di dalam otot.

(Ismaryati, 2008) mengemukakan, bahwa "Melakukan program latihan yang baik, dikombinasikan dengan nutrisi yang tepat, menemukan bahwa berat badan tidak berubah banyak sampai beberapa bulan. Namun jika mengukur persentase lemak tubuh secara teratur menemukan bahwa telah kehilangan lemak yang digantikan dengan otot yang lebih berat. Bertambahnya massa otot, sering dikenal dengan nama hypertrophy 
Jurnal Sporta Saintika

P-ISSN 2502-5651

E-ISSN 2579-5910

adalah keadaan dimana serabut otot bertambah besar/tebal. Semakin banyak/maksimal serabut otot direkrut dalam suatu sesi latihan, maka semakin besar potensi perkembangan massa otot.

Dengan latihan senam aerobik bila berat badan bertambah maka terjadi peningkatan massa otot, sebaliknya bila berat badan berkurang makan akan terjadi penurunan massa otot. Berkurang berat badan = bertambah massa otot. Karena pada senam aerobik melibatkan hampir seluruh otot-otot besar dalam tubuh yang dapat digerakkan. Keterampilan latihan gerakan senam aerobik dipadukan dengan iringan musik yang berguna untuk menentukan tempo latihan, mengatur langkah, dan gerakan memberikan dorongan sehingga meningkatkan motivasi anggota senam.

\section{KESIMPULAN}

Berdasarkan analisis data dan pembahasan yang telah dipaparkan terdahulu, maka dapat dikemukakan beberapa kesimpulan sebagai berikut: (1) Latihan senam aerobik memberikan pengaruh yang signifikan terhadap penurunan berat badan $t_{\text {hitung }} 2,186>t_{\text {tabel }} 1$. 782. Nilai rata-rata pretest $66,86 \mathrm{~kg}$ dan posttest $66,12 \mathrm{~kg}$. Terdapat penurunan $0,74 \mathrm{~kg}$. (2) Latihan senam aerobik memberikan pengaruh yang signifikan terhadap penurunan persentase lemak tubuh $t_{\text {hitung }} 3,285>t_{\text {tabel }} 1.782$. Nilai rata-rata pretest $40.45 \%$ dan posttest 37, $18 \%$, Terdapat penurunan 3, $27 \%$ dan (3) Latihan senam aerobik memberikan pengaruh yang signifikan terhadap massa otot $t_{\text {hitung }} 1,835>t_{\text {tabel }} 1$. 782. Nilai rata-rata pretest 37, 72 dan posttest 37,63, Terdapat penurunan nilai sebesar 0,09.

\section{DAFTRA PUSTAKA}

Arikunto, S. (2006). Metode Penelitian Kualitatif. Bumi Aksara.

Depdikbud. (1996). Ketahuilah Tingkat Kesegaran Jasmani Anda (Jakarta (ed.)). Pusat Kesegaran Jasmani dan Rekreasi.

Eka Novita Indra, E. A. A. ,. (2016). Perbedaan Pengaruh Frekuensi Latihan Senam Aerobik

Terhadap Penurunan Persentase Lemak Tubuh Dan Berat Badan Pada Members Wanita. Medikora, 15(1), 39-51. https://doi.org/10.21831/medikora.v15i1.10071

Gusvominesia, W., Padang, U. N., Gymnastics, A., Aerobik, S., \& Impact, M. (2019). Tabel (13.83 > 1.725). 2, 321-328.

Indah, D. (2016). Pengaruh Latihan Senam Aerobik terhadap Penurunan Kadar lemak Anggota Senam Sanggar Kebugaran Muslimah Centre Padang. I(1), 1-9.

Ismaryati. (2008). Tes dan Pengukuran Olahraga. Cetakan 2. LPP UNS Press. Jasmani, P. (2017). Pendidikan Jasmani, Olahraga, dan Kesehatan. Pusat Kurikulum dan 
Jurnal Sporta Saintika

P-ISSN 2502-5651

E-ISSN 2579-5910

Perbukuan, Balitbang, Kemendikbud.

Lingga, L. (2012). Sehat dan Sembuh dengan Lemak. PT Elex Median Komputindo.

Nurhidayah, N. (n.d.). Pengaruh Senam Dan Aerobik Terhadap Resiko Jatuh Pada Lansia Di Desa Sobokerto Kecamatan Ngemplak Boyolali Jawa Tengah Ninik Nurhidayah. 22-27.

Pratiwi, I., \& Basri, M. (2018). Window of Health: Jurnal Kesehatan , Vol . 1 No . 2 (April, 2018 ) Pengaruh Senam Aerobik Terhadap Penurunan Berat Badan Remaja Obesitas di SMP Katolik Rajawali Makassar Tahun 201776 / Fakultas Kesehatan Masyarakat Universitas Muslim Indonesia Window . 1(2), 76-82.

Ramayulis, R. dan L. C. L. (2008). 17 Alternatif Untuk Langsing. Penerbit Plus.

Septiyadi, E. (2004). Terapi Obesitas dengan Diet. Restu Agung.

Sherwood, L. (2011). Fisiologi Manusia dari Sel ke Sistem. Buku kedokteran.

Sihombing, A. S. dan R. S. D. (2011). Metode Penelitian Keolahragaan. Yuma Pustaka.

Siska. (2014). Pengaruh latihan senam aerobik multi impact dan low impact terhadap penurunan persentase lemak tubuhDan peningkatan massa otot(Studi Eksperimen Pada Anggota Ozone Fitness dan Aerobik Padang) Tesis. Pascasarjana. UNP.

Siska. (2019). HUBUNGAN TINGKAT KESEGARAN JASMANI DENGAN KECERDASAN UNIVERSITAS NEGERI PADANG Oleh Siska STKIP Rokania Article History Received: March 2019 Accepted: June 2019 Published: July 2019 Keywords Abstrak. Jurnal Pendidikan Rokania, 4(2), 220-232. https://ejurnal.stkiprokania.ac.id/index.php/jpr/article/view/214.

Supariasa, I Dewa Nyoman, dkk. (2002). Penilaian Status Gizi. EGC.

Supariasa, I Dewa Nyoman, D. (2002). Penilaian Status Gizi. EGC.

Utomo, G. T. (2012). Journal of Sport Sciences and Fitness. 1(1).

Wiarto, G. (2013). Fisologi dan Olahraga. Graha ilmu. 